\title{
The possibilities of concert pedagogy in Hungary
}

\author{
JUDIT VÁRADI* (1)
}

Faculty of Music, University of Debrecen, Debrecen, Hungary

\section{THEMATIC ARTICLE}

Published online: July 13, 2020

(C) 2020 The Author(s)

\begin{abstract}
In public education the main emphasis is on conveying lexical knowledge instead of making students love music, play music together and do creative musical exercises. Teaching music has become too theoretical, and it is almost entirely dominated by literary data. Although teachers have some freedom to make slight changes in the curriculum, the number of music lessons is very low. Concert pedagogy is a progressive pedagogical initiative of the 20th-21st century, which aims to present the values of art at the original location of artistic activity, in an experience-filled environment, just as other branches of experience pedagogy do. The educational activity of experience pedagogy takes place in an extracurricular framework to complement public education. Art education is based on going through and enjoying an experience, which, however, cannot be taught, only explored and reinforced. In the traditional approach, intellectual education comprises two tasks: intellectual informing and formation (Bábosik, 1997). Intellectual development occurs through the process of transferring and internalising scientific knowledge, which is presented in the form of subjects. Bábosik highlights that intellectual and cultural needs can evolve when it is achieved that children like to learn, which generates the desire for novel knowledge.
\end{abstract}

\section{THEORETICAL FRAMEWORK}

In Hungary, teaching music is still based on Kodály's ideas of education, whose philosophy of musical education was relevant from kindergarten to professional musical higher education. As early as in 1929, in his essay titled Children's Choirs, he was occupied with the following question: "What should we do? Teach music at school in such a way that it becomes a source of joy to pupils rather than misery and fill them with lifelong thirst for noble music" (Kodály, 1982, p. 207). According to his concept, musical ability can be developed in all children with healthy

*Corresponding author. E-mail: judit.varadi.06@gmail.com 
auditory organs and a sound mind (Kokas, 1972). With his guidance, primary schools specialised in music were founded. Several transfer studies have shown the beneficial effects of specialised musical education on personality development and its positive impact on skills and abilities required for other disciplines (Bácskai, Manchin, Sági, \& Vitányi, 1972; Barkóczi, \& Pléh, 1978; Kokas, 1972). The Kodály concept is not the product of the era, although that is when the approach enjoyed adequate support the most. It is hardly possible to summarise Kodály's education principles. This philosophy of education and music education, which is often misinterpreted as "Kodály method", is not a detailed methodology or curriculum but a collection of Kodály's insights and guidelines, which were passed on to us in speeches, publications, quotes, or manuscripts. Proponents of Kodály's pedagogy used these fragments to assemble his concept of music education.

Recently the discussion of values that can be found in the theory and practice of musical education has revived and new answers are being sought to the question of what it means to teach music in the spirit of Kodály. Reaching back to the original concept, the main features of the system are to be summed up.

What underlies the concept is the idea of making music democratic, which is best expressed by the call for "letting music belong to everyone". The concept itself means the sum total of his oral and written instructions, his philosophy of education and his compositions written with a view to facilitating musical pedagogy.

Acquiring artistic values and taste involves a variety of pedagogical influences. Research conducted by Strém in 1988 corroborates that the teacher's personality is cardinal in shaping the attitude towards music (Strém, 1988). At schools teaching art is in a difficult situation. Teaching singing has been thrust into the background, so children can hardly have any experience of folk music or classical music culture (Váradi, 2019). Naturally, this has its disadvantages, which is already shown by the decreasing audiences attending classical concerts. Forms of shallow entertainment and superficial free time activities are becoming widespread.

Today's research also proves the same effects of learning music. Children who take part in extracurricular musical education have significantly better academic results than those who do not in spite of the fact that learning music takes up a lot of their time (Szücs, 2019).

\section{LISTENING TO MUSIC IN THE SCHOOL: GOALS AND TASKS}

The main objective of listening to music is to give pupils delight in music both consciously and spontaneously. If the session is well-prepared, it can create the atmosphere necessary to receive the work of music to be listened to. If the teacher relies on what pupils already know about music and gives them a thorough treatment of new information, pupils will regard that piece as being close to them since they are familiar with all the processes underlying them.

Conscious listening to music develops the ability to concentrate. It also improves musical memory through the recognition of the identity and similarity of, or difference between the various musical constituents. If pupils are made to observe the characteristic features of instruments, it also promotes the formation of timbre distinction.

The curriculum for the junior section of primary school gives an overall view of nearly all styles, thus laying the foundations for a sense of them. The way the compositions are processed 
focuses mainly on emotions and the perception of tonal characters as well as the progresses of music with special regard to the age group concerned (Szücs, \& Héjja, 2017).

Listening to music can take on two different forms. The attention of listeners can either be drawn to minute details or they can be permitted to perceive the given composition as a whole, without being affected by any external influence. In this latter case, the whole composition is analysed after it has been listened to, which is generally followed by some synthesis. Pupils' coming across the composition again then means something like their awakening to its values, which can be a new experience. This age group is not yet able to divide their attention, so they should be given just one aspect of the composition for observation. The music should be replayed every time a new point of view is introduced, which facilitates the rebuilding of the whole sounding image (Váradi, 2016b).

To decide what kind of music is chosen for listening, it is necessary to consider whether it is varied enough and whether the "hide-and-seek" game of the different parts and voices is capable of maintaining pupils' interest throughout.

It is not at all important to search for subject matter, images, colours or phenomena in music, since its relationship to reality is much more indirect. Every composition has its peculiar character and mood. To be able to decode them, one should be familiar with the components forming them, and it is this familiarity that one should strive for. Kodály put great emphasis on education because he believed that culture cannot be received or inherited but it has to be acquired again and again by each generation. He thought "it should start at primary school. Our goal is to raise people for whom music, I mean good and artistic music, is a must" (Szabó, 1996, p. 111).

A positive change was brought about in music teaching in public education by the curriculum introduced in 1962. Aesthetic education was declared as the goal of teaching music, and listening to music was included in the curriculum. Although listening to music is as old as music itself, it was a novelty at schools without any methodology, so it required a lot of innovative professional knowledge from teachers. As early as that, in a training plan for teachers, schools were advised to contact other musical institutions such as music schools or choirs to facilitate the live presentation of music (Kiss, 2003). Later the curriculum was expanded to cover, besides folk music, instrumental music, and besides various genres and the classic works, 20th-century music such as the works of Britten, Pendereczki, Honegger, Szokolay, Petrovics, Kurtág and Durkó (Laczó, 1979). Getting students into the habit of listening to music is an important task of musical education. There are lots of approaches to deal with the listening material in an enjoyable way, and there are also lots of arguments for introducing listening to music systematically. For instance, listening to music, apart from singing, is our most direct contact with music.

Listening to music is already part of the educational programme of kindergartens, and these skills are to be developed further in the first years of primary school. The activity requires considerable concentration, which has to be practiced. It is from the first years of primary school that children have to be taught to receive the music they hear actively rather than just bear it passively. They also have to learn how to choose from the unselected musical influences they are exposed to. Music classes will best fulfil their mission if they include listening to music as reception, singing and reading and writing musical notation as reproduction, and improvisation as creation, which is the best way of developing one's imagination. The goal of listening to music, along with singing, at lower primary school is to arouse children's interest in music and thereby shape their musical taste as well as their aesthetic and emotional sensitivity. Creating the necessary atmosphere for the reception of a piece of music is a question of well-planned 
preparation. Children can identify with the entire work if they understand every phenomenon precisely and incorporate new information with the help of their existing musical knowledge. Listening to music with full awareness develops concentration, musical memory and thinking through the recognition of the sameness, similarity or difference of various musical components. Auditory perception develops timbre recognition through the observation of the characteristics of various musical instruments. Children should be familiarised with musical pieces gradually: first they should be shown short excerpts, to be followed, as their attention span grows, by longer excerpts or entire pieces. Purposeful practice can develop one's innate ear for music to ever higher levels, as far as intellectual artistic aural skills (Varró, 1989). Systematic musical training teaches the future listener to concentrate on the sounds they hear with all their attention and to ignore all non-musical stimuli. "Masterpieces demand complete dedication and absorption from the listener, which then bear their marvellous fruit" (Furtwängler, 1969, p. 56).

There is a strong correlation between the high amount of exposure to classical music in childhood, linked with positive emotions, and the development of classical musical competencies (Mende \& Neuwöhner, 2006). The acquisition of a thorough musical knowledge including, for example, familiarity with different musical styles, presupposes the individual's predisposition.

The most effective way of creating a musical experience is a live performance, which has a greater emotional appeal to children. A concert experience cannot be reproduced; it is unique and unrepeatable for the listener. Live presentation of music should be part of public education, too. The simplest and most natural form of listening to music is the teacher's presentation of the songs in class. Students can see how sounds are produced, how the performer breathes and what his or her gestures are like, so they are familiarised with the technical process. Ideally, musical instruments are also used; depending on the teacher's skills, the songs can be accompanied on the piano, which is a great opportunity for experiencing the joy of making music together. Besides, instruments make it possible to present and analyse simple musical forms and have students recognise them. With some luck, there are students who learn music at a music school or in any other way. Of course, their performance is supposed to reach a certain level, which makes cooperation with their music teachers necessary.

During the past centuries, teaching music at schools has changed a great deal, and the past decades have seen a lot of changes in Hungary as a result of the reforms in public education. Today's curriculum, besides folk music, mainly focuses on classical music, but it all ends with the works of Kodály and Bartók. Teaching music at our schools has a retrospective approach, emphasising the music of the past. Nowadays contemporary music has become distanced from its audience, who expect a different concert experience from what most contemporary concerts can offer. It is worth giving some thought to the fact that neither mainstream music life nor the concert-going audience in Hungary have acknowledged 20th-century music yet (Surányi, 2008, p. 95). Modern music can boast renowned artists as patrons; nevertheless, it still has a small audience because it does not offer the usual and expected catharsis. Still, children can be helped creatively to understand and interpret contemporary music if the appropriate preparations are made and their inclination towards experimentation and research are relied on. Csaba Szabó's book (1977) gives guidance to teachers on teaching contemporary music. Today it is László Sáry's (1999) creative musical exercises that are considered outstanding as they are suitable for all age groups regardless of previous studies of music. They are not about teaching but the experience of discovery through musical expression. The self-contained pieces of music are beneficial to the development of memory, concentration and improvising skills. The way they 
are played largely depends on the players' creativity and imagination. The sense of success coming from playing boosts one’s self-confidence (Urbánné, 2002).

Introduced in 1998 and still in force, the National Curriculum contains those basic elements of general education that no individual can dispense with. The compulsory material was determined with a view to the needs of all school types and in a way that the goals that had been set could be achieved within just $70 \%$ of all the classes, which allowed the inclusion of complementary material and requirements. To enable schools to apply the general outlines to their special needs, the topics to be covered were formulated not in terms of separate subjects but for broader areas of culture.

For singing and music to be effectively taught, children must be given an overall view of the relation of the compositions studied to geography, history or literature. Pupils must be urged to complete their musical experience with reading, listening or watching films for new information according to their individual tastes. Literature, history - including the history of religion geography, foreign languages, mathematics, physics, and other areas of art can all be instrumental to giving a new approach. What children can experience in such a way is that music is as inalienable a part of our life as anything else, that no phenomenon in the world exists in and for itself but is closely and mutually linked with others.

When the National Curriculum was introduced, the number of music and singing classes at schools continued to decrease (Váradi, 2016a). What can be seen is that the number of classes devoted to singing and music has never been so small for the last 150 years as it is today, compared not only to all subjects taught but also to other fields of teaching art.

In 2015, the Committee for Everyday Singing was established with the purpose of creating a method to provide the possibility of singing every day in school, which would result in a larger emphasis on children's music education. The Hungarian State Opera House joined the initiative in 2019 by compiling a collection of the most popular opera excerpts, which will be made available to every school for free. So far, this has been the only result of the efforts directed towards the reform of music education in public education. The revision of the National Core Curriculum began in 2017 but has remained in the proposal stage ever since. The guideline does not prescribe specific pieces of music as it offers instructions on genre and style only, which permits music teachers to incorporate into the local curriculum compositions which are adequate for children's age as well as their social and musical background. The recommended number of weekly sessions for the "Singing and Music" subject is 2 for Grades 1-4, and 1 for Grades 5-8. In the first two years of secondary education, the recommendation is 1 session per week, while the advised curriculum does not contain music education for the last two years. Although the most recent proposal provides more favourable recommendations than the one before with respect to the number of sessions, the dominant role of art education up to the age of eighteen, which is advocated by György Vashegyi, President of the Hungarian Academy of Arts, is still far away, despite the fact that Hungary is the country where Zoltán Kodály was born and exerted his influence.

\section{EXPERIENCE AND CONCERTS}

There is a great difference between hearing and listening. The best one can do is go to a concert where there is real live music. That is how one can present oneself with a lovely night, leaving behind the hustle and bustle of everyday life and indulge in music. 
Training to listen to music is an important part of musical education, which is not an easy task. It has been proved that it has a positive influence on developing certain skills needed for it as well as on the growth of the whole personality. It improves concentration, musical memory and thinking, musical and acoustic hearing, internal imagination and and the ability to properly appreciate values.

Live music programmes are the best means of conveying positive musical experience. Not each important detail can be presented with live music, but at classes of singing pupils' ability to recognize instruments and voices can best be developed through live music shows, which are much more effective than playing records and exert a positive emotional influence on them.

Live music illustrations can be applied in various forms: the teacher singing, the teacher playing an instrument, presenting musical instruments, pupils playing musical instruments, looking for out-of-class opportunities.

When sound recording was invented, an era in the history of music had finished. No personal presence was necessary during performances. With the spread of record players, famous musicians' records could be heard without going out. Sound recording had the same revolutionary influence as the invention of printing music 400 years before.

An effective tool to create musical experience is live music performance, which captures the children's emotions. The experience of a live concert cannot be replicated, the listener's experience is unique and unrepeatable (Wilheim, 2010).

Non-formal teaching is not exceptional in musical education (Váradi, 2016a). As the importance of the education of a concert-going audience was realised in Europe and America in the early 20th century and a distinct children's culture was taking shape, there were various initiatives adjusted to the needs of the age group attempting to draw young people's attention to the importance of listening to music.

During the past years there have been some exemplary initiatives in our country to elaborate the programme of presenting music in an enjoyable way. The prevailing law on performing arts (2008/XCIX) treats the art education of school-age children as a priority in the General Provisions of Chapter I stipulating that professional ensembles facilitate children's and young people's access to works of art and contribute to the fulfilment of the state's and local governments' educational tasks. That is to say, the task is given, but the methods and methodology are still to be worked out. The guidelines for curricular education are to be found in the National Curriculum, but extracurricular musical education has plenty of untapped potential.

In Hungary there are a lot of professional orchestras and concert organisers committed to young people's musical education. When planning a so-called experience concert, one must keep several factors in mind. The best choice is, of course, to compile a concert programme that is adjusted to what students have learnt in music classes. Based on that, the concert helps conscious reception through the magic of live music. Besides, concerts should be colourful and interesting enough to capture the young audience's attention. Because of their young age and openness, young people are able to show enthusiasm for unusual sounding and contemporary music.

\section{CONCERT PEDAGOGY}

In 2013 concert pedagogy appeared in the curriculum of Hungarian higher art education. The required complex expertise includes topics from education theory, music psychology, sociology, 
music aesthetics, music pedagogy, music history, music theory, communication, marketing, and management. To carry out music pedagogy in a successful way, the content of the performance must be compiled from adequate musical pieces, with particular regard to the location, time, target group, as well as the infrastructural and technical background. Detailed musical knowledge, varied and collected communication skills, and multi-tasking abilities are also required. It is essential to assess the characteristics of the age group and shape the message in a flexible way to meet the dominant group's intellectual level of perception. A sense of time and proportion is also needed. It must be kept in mind that the primary goal of the performance is musical presentation. Furthermore, it is instrumental to maintain attention in a natural, spontaneous, and humourful way, which is a prerequisite for the success of the concert. The initiative, which originates from the internal motivation of professional communities and individuals, blends into systematic training as an educational innovation.

Concert pedagogy forms part of future music teachers' education as curricular training at various levels to make them capable of subsequently organising extracurricular events in a professional manner. Youth concerts do not have a prescribed methodology; the success of a performance is largely determined by the preparation, creativity, and innovative thinking shown by the moderator, that is, the person in charge of concert pedagogy. With its traditional methods, public education can do little to enhance the efficiency of art education, but the tools of concert pedagogy, with certain limitations, may be incorporated into music lessons in school. Thus, such performances could significantly contribute to enriching teachers' methodological culture and forming their perspective. The students' experience provides motivation to discover musical values for them and also for the teachers. As a result of the performances, the comprehension and application of acquired knowledge improve. Consequently, the effect of concert pedagogy can be explored at multiple levels; the participating child audience, teachers, and university students all play a different role in the process. The system of goals, however, is complementary: through concert pedagogy, all become acquainted with the efficiency of experience-based education, as well as with activity-centred and creative methods, which are principal elements of leading pedagogical methodology in formal and informal art education.

\section{SOUND - GAME - MUSIC EXPERIENCED BASED YOUTH CONCERT, RESEARCH PROBLEM AND HYPOTHESIS}

Our mission is to shape the artistic and musical taste of children and young people who do not receive art education. We may only capture the attention of children if we entertain them at the same time; however, we can only enrich their lives by expanding their intellect (Bettelheim, 1985). We have organised and staged various educational youth performances in the last decades. In conformity with the academic year, three performances are held for students. Our goal is to get children acquainted with live music, classical instruments, and the craft of playing them (Váradi, 2017).

In Hungary, multiple professional symphony orchestras and concert organisers are devoted to the musical education of youth. One must bear in mind a number of different factors when organising an extracurricular youth experience concert. Naturally, the content of the concert is optimal if it is in connection with the curriculum of music classes, based on which the magic of live music can be even better grasped. It is important that these performances should draw the 
attention of young listeners through their colourfulness and interestingness. The age and openness of young people allows them to be also passionate about unusual sounds and contemporary music.

At the University of Debrecen Faculty of Music, we have organised and staged various educational youth performances in the last two decades with the Foundation for the Art of Future. In conformity with the academic year, 3 different performances in 18 occassion are held for 1,500 students. Our main target group consisted of children in the first half of primary education (age 6-11). Alongside them, there were also children from preschool education (age 5-6) and the second half of primary school (age 11-14) present at the performance. Children took part from 18 to 20 institutions in Debrecen and from other schools in the area. Some institutions even hired a bus to take the pupils to the event from their towns, Our goal is to get children acquainted with live music, classical instruments, and the craft of playing them. A key element of our mission is to form the preferences of children and young people who do not participate in art education, so that they may become interested and sophisticated adults.

The diverse repertoire of concerts curated at a high artistic standard familiarises the audience with various instruments as well as several genres and styles of music. Combining different branches of art expands the traditional receptive attitude and thus creates a complex experience. In a similar way to Klára Kokas' pedagogy, which converts certain artistic codes into other branches of art, the methodology of concert pedagogy also incorporates the movement improvisation of the musical material or the connection of directed dance instruction with previously introduced pieces of music. The creativity of improvisation and the situational understanding of creative curiosity are both accompanied by the experience of self-actualisation (Mérei, as quoted by Gabnai, 1999).

Besides the performed compositions, there are various factors which determine as to whether the audience of children can enjoy the concert. There is an almost infinite number of ways in which the audience can be involved in the performance and interactivity may be achieved; the exact method is up to the host and the person who decides on the content of the event (Váradi, 2010). Examples include a song which is sung together with the audience, a polyphonic piece which makes use of sounds produced by the body, a sound collage of objects in a pocket (Sáry, 1999), improvised or directed dance instruction, or even movements made while sitting.

It offers a great experience for the young audience if they are allowed to attempt to play the instruments themselves. Children are always surprised at how different the instrument sounds in professional hands. We have even organised so-called dance houses during some concerts, which means that children can learn the adequate folk dance for the folk songs taught at the event. To illustrate the conductor's role, children are taught what basic movements a conductor makes, and are then asked to replicate them in front of the orchestra. By listening to the various ways in which the same piece can be performed, children can learn the conductor's role through experience.

There are several alternatives for subsequently re-living the experience. Distributing the sheet music of a composition or folk music sung together could generate multiple positive effects. The surprise is elevated by the recipient's joy, the observation of the sheet music, which will always be a memory for the previously learnt musical material at every encounter.

Traditionally, we organise drawing contests in connection with our youth concerts. This year, children's works were displayed in the music section of Méliusz Juhász Péter County Library. Visual representation is an important form of expression during childhood, and it dates 
back to the origin of mankind. Drawings reflect the atmosphere and impressions of the concert and music as well as children's positive or negative experiences through their creative perspective. Throughout history and different epochs, it has been natural to connect different branches of art, to combine visual arts and music. The desire to represent what cannot be seen is ancient (Simon, 2013). Many artists painted musical instruments and musicians, which now provides an important source for music historians (Váradi, 2010). Painters depict rhythm, melody, and fluid, volatile musical structures visually. At the same time, visual art inspires music, so we may conclude that there has been a strong connection between music and visual art, which is supported by centuries of evidence from the history of art.

Children's works are centred around a topic and are translated through an inner filter to external expression (Vass, 2011). From the point of view of pedagogy, analysing the drawings can be of significant help in the planning of future concerts as we are able to assess what aspect of the concert was important to the children and what kind of questions they had thereafter. Our study does not aim to evaluate children's drawing skills nor to investigate gender differences in the quality of visual expression. All drawings have been carefully analysed using the monographic method, and the most typical ones are presented in this study.

Children, by remembering and reliving the experience, depicted in their drawings what they saw, heard, or felt during the concert. Visual communication can reveal emotions without words, which proves how powerful art really is. Drawings may tell a story through their narrative (Malchiodi, 1998). Pupils express their experience by condensing their emotions into a drawing (Vass, 2013). It is important to remember that drawing requires time. In the weeks following the concert, children, between the ages of 7 and 11, prepared their works in class or in their free time during day care. The success of a concert can be excellently measured by the number of drawings we receive after it.

The rich colourfulness of the drawings illustrates the diversity of the performance, while the careful depiction of certain details indicates the moment which caught the listeners' attention the most.

The drawings can be sorted into three main groups by choice of topic: some children depicted the visual experience of performers and the concert hall, others focused on a specific detail of the performance, while certain pupils were inspired by the event and created more abstract works. The latter drawings are the closest to synaesthesia as sounds inspired colours and visions. We have been astonished by the dynamism of the scenes, the proportionate use of space, the strong and well-defined contours, the unique choice of colours, and the marvellous creativity the drawings, inspired by the diverse performance, demonstrated. This provides us with the necessary motivation to create such uplifting and diverse concerts which are appropriate for the age group. The music played by qualified artists contributes to the formation of adequate listener attitudes.

Through the visual expression of the volatile musical experience of a live performance, different branches of art intertwine.

As a long-term result of our youth experience concerts, some have started to study music and others have even chosen to become music teachers because they saw an instrument during the performance which they immediately wanted to learn how to play. A young teacher, who participated in such concerts in primary school, now takes her pupils to join in the same experience. 
For the teachers we carried out an empirical study using a newly developed method. Our survey consisted partly of closed-ended, multiple choice questions but mostly of open-ended, descriptive ones. The respondents were teachers, who were asked about their degree, everyday work at school, experience in art and, mainly, music education. Teachers who have already attended such youth concerts with their class were also surveyed about their pupils' attitudes towards classical music and about the complementarity of formal education and such extracurricular events. The findings were presented in April 2017 at a musical pedagogy conference, which celebrated the 50th anniversary of tertiary teacher education in Debrecen (Váradi, 2017). While respecting anonymity, we have found based on the answers to the open-ended questions that teachers have mixed opinions on youth concerts. Many of them agree that youth concerts should be planned with careful attention to the age of the listeners, otherwise pupils might not be able to appreciate the performance, they may get bored, misbehave, or pay more attention to the surroundings than the content. Some, however, are hesitant to take their class to a youth concert because they think their pupils are not able to sit in quiet. Several teachers emphasise the importance of preparation and setting the mood for the concert. According to a respondent, "children do not like certain things because they do not know them". Many teachers observe the connection between attitudes towards art and cultural capital acquired at home, therefore they believe it is important that schools organise these events for children as some of them do not have the opportunity to see classical instruments in person otherwise. According to several accounts, children "become calm, happy, and joyful" after concerts, which "exert a positive psychological influence". Most teachers agree that concerts provide pupils with a valuable experience.

\section{SUMMARY}

Music in itself can only have a positive effect. It has several fields of application, in which it does not lose anything of its expressive power but can be combined with similar forms of expression (eurhythmics, theatre, film, fine arts, literature) or used as a kind of help in areas like sports or musical therapy in a way that emphasises one of its aspects but does not discontinue others.

Recently the discussion of values that can be found in the theory and practice of musical education has revived and new answers are being sought to the question of what it means to teach music in the spirit of Kodály.

At schools teaching art is in a difficult situation. Teaching singing has been thrust into the background, so children can hardly have any experience of folk music or classical music culture. Forms of shallow entertainment and superficial free time activities are becoming widespread.

I hold the view that presenting the values of classical music must be the primary concern of both performer and recipient, since the relationship between them is reciprocal by nature, My aim is to find my way in the rapidly changing world we are living in by reconciling long term values with the requirements set by our age.

Funding sources: No financial support was received for this study.

Authors' contribution: The author is the leader of the Sound-Game-Music youth concerts, collected and analysed the data about extracurricular activities in the Hungarian school system with the possibilities of concert pedagogy. No other author did contribute to the manuscript. 
Conflict of interest: The authors declare no conflict of interest.

\section{ACKNOWLEDGEMENTS}

No additional acknowledgements.

\section{ABOUT THE AUTHOR}

Judit V'radi PhD is a pianist and associate professor. She obtained a degree as a piano professor, music teacher, choir leader, répétiteur, and cultural manager. She received her $\mathrm{PhD}$ at the University of Jyväskylä, Finland. She lectures at the Faculty of Music of the University of Debrecen. She is art director for the Young Musicians' Summer Academy. She is a lecturer at the Partium Christian University in Oradea, Romania. Since 2015 she is supervisor and lecturer at the Doctoral School for Humanities of the University of Debrecen, research leader of the Survey of possibilities of extracurricular art activity in Hungary supported by the Hungarian Artistic Academy Research Institute of Art Theory and Methodology. She is the founder of the International Music Pedagogy Conference in Debrecen.

\section{REFERENCES}

Bábosik, I. (1997). A modern nevelés elmélete [The theory of modern education]. Budapest: Telosz Kiadó. Bácskai E., Manchin R., Sági M., \& Vitányi I. (1972). Ének-zenei iskolába jártak [They were student of singing and music school]. Budapest: Zenemúkiadó.

Barkóczi I., \& Pléh Cs. (1978). Kodály zenei nevelési módszerének pszichológiai hatásvizsgálata [The effect of Kodály's musical training on the psychological development]. Kecskemét: Kodály Zoltán Zenepedagógiai Intézet.

Bettelheim, B. (1985). A mese büvölete és a bontakozó gyermeki lélek [Magic of the tale and the developing childlike soul]. Budapest: Corvina Kiadó Kft.

Furtwängler, W. (1969). Zene és szó [Music and words]. Budapest: Gondolat Kiadó.

Gabnai, K. (1999). Drámajátékok. Bevezetés a drámapedagógiába. Helikon Kiadó.

Kiss, H. (2013). Zenehallgatás az általános iskolában [Listening to music in elementary school] In: Iskolakultúra (pp. 22-32). https://epa.oszk.hu/00000/00011/00175/pdf/EPA00011_iskolakultura_2013_5-6_ 022-032.pdf.

Kodály, Z. (1982). Visszatekintés. Összegyüitött írások, beszédek, nyilatkozatok I [Looking back. Collected writings, speeches, statements]. Budapest: Zenemükiadó.

Kokas, K. (1972). Képességfejlesztés zenei neveléssel [Development of musical ability with education]. Budapest: Zenemúkiadó.

Laczó, Z. (1979). Az ének-zene tanítás célja és feladatai. Zenehallgatás. In: Az általános iskolai nevelés és oktatás terve. Tantervi Útmutató. Ének-Zene 1-4. osztály [The goal and tasks of music education. Listening to music. In: Curriculum guide. Singing and music in classes 1-4]. Budapest: Tankönyvkiadó. 
Malchiodi, C. A. (1998). A gyermekrajzok megértése [Understanding childrens' drawings]. Budapest: Animula.

Mende, A., \& Neuwöhner, U. (2006). Wer hört heute klassische Musik? - Musiksozialisation, E-Musik-

Nutzung und E-Musik-Kompetenz. Das Orchester Magazin (Mainz: Schott), 54/12, 10-14.

Sáry, L. (1999). Kreatív zenei gyakorlatok [Creative music activities]. Pécs: Jelenkor Kiadó.

Simon, T. (2013). A zene és a képzőmüvészet közös nyelve [A common language of music and fine arts].

Parlando: Zenepedagógiai folyóirat.

Strém, K (1988). Vitairat a zenei müvelődésről [Discussion about musical culture]. Budapest: Zenemúkiadó.

Surányi, L. (2008). Megszólít vagy elvarázsol? A zene szelleméről [Does it address or charm you? The spirit of music]. Budapest: Typotex.

Szabó, H. (1996). A magyar énekoktatás kálváriája [The Calvary of Hungarian Singing Education]. Budapest: Szerkesztői kiadás.

Szabó, Cs. (1977). Hogyan tanítsuk korunk zenéjét [How to teach the music of our time]. Bukarest: Kriterion Könyvkiadó.

Szücs, T. (2019). Alapfokú müvészeti iskola egy esélynövelö iskolatípus [Elementary School of Art is a type of school that enhances chances]. Debrecen: Debreceni Egyetemi Kiadó.

Szücs, T., \& Héjja, E. B. (2017). The institutional network and state of music education in Hungary. Hungarian Educational Research Journal, 7(3), 39-54. https://doi.org/10.14413/HERJ/7/3/5.

Urbánné Varga, K. (2002). “Rakják, rakosgassák magas Gyivó várát. ..” [Building high Gyivó castle...] In: Hang és lélek. Új utak a zene és társadalom kapcsolatában (pp. 9-31). Budapest: Magyar Zenei Tanács.

Váradi, J. (2010). How to educate an audience to acquire a taste for classical music. Jyväskylä, 2010. ISBN: 978-951-39-3897-0. Retrieved from: https://urn.fi/URN:ISBN:978-951-39-3898-7.

Váradi, J. (2016a). Incorporating experience-based concerts into public education. Studia Universitatis Babes-Bolyai Series Musica, LXI(2), 7-18. Retrieved from: https://rt.ubbcluj.ro/st-musica/studiamusica-2-2016.pdf.

Váradi, J. (2016b). The goal of listening to music in: In the Labyrinth of (Musical) art. Sosnowiec: Wyzsza Szkola Humanitas, Poland. ISBN: 978-83-65682-44-4.

Váradi, J. (2017). Piano and experience. In M. Strenacikova (Ed.), Banská Bystrica: Akadémia umení v Banskej Bystrici, Slovakia. Klavírne diela slovenskych skladatel'ov. ISBN: 78-80-89555-75-8.

Váradi, J. (2019). Az élménypedagógia szerepe a művészeti nevelésben. Magyar Mưvészet. 2019/3. ISSN: 2064-3799.

Varró, M. (1989). Zongoratanítás és zenei nevelés [Teaching piano and music education]. Budapest: Editio Musica.

Vass, Z. (2011). A képi kifejezéspszichológia alapkérdései [The basic questions of visual expression psychology]. Budapest: L'Harmattan Kiadó.

Vass, Z. (2013). A rajzvizsgálat pszichodiagnosztikai alapjai [The psychodiagnostic basis of the drawing examination]. Budapest: Flaccus Kiadó.

Wilheim, A. (2010). Esszék. Írások zenéről [Essay. Writings about music]. Budapest: Kortárs Kiadó.

Open Access statement. This is an open-access article distributed under the terms of the Creative Commons Attribution 4.0 International License (https://creativecommons.org/licenses/by/4.0/), which permits unrestricted use, distribution, and reproduction in any medium, provided the original author and source are credited, a link to the CC License is provided, and changes - if any - are indicated. (SID_1) 